JURNAL RESPIRASI

JR

Vol. 5 No. 2 Mei 2019

\title{
Perbaikan Kualitas Hidup pada Pasien Solitary Fibrous Tumor Mediastinum: Perspektif Kemoterapi Paliatif
}

\author{
Aryo Dirgantara Putra ${ }^{1,2 *}$, Winarinani Koesoemoprodjo ${ }^{2}$ \\ ${ }^{1}$ RSUD Abdul Wahab Sjahranie, Samarinda, Kalimantan Timur, Indonesia \\ ${ }^{2}$ Departemen Pulmonologi dan Ilmu Kedokteran Respirasi, Fakultas Kedokteran, Universitas Airlangga/RSUD Dr. Soetomo, \\ Surabaya, Indonesia
}

\begin{abstract}
Background: Mediastinal solitary fibrous tumor (SFT) is a rare spindle cell neoplasm. Approximately 1 to $8 \%$ of these intrathoracic tumors have been reported to occur in the mediastinum. The chief complaints of mediastinal SFT are cough, shortness of breath or chest pain, or may occur as asymptomatic incidental mass. The treatment of choice for SFT is extensive surgical resection. However, when the tumor cannot be removed surgically or when metastases occur, chemotherapy and or radiotherapy can be proposed as palliative treatments. Case: A 19-year-old man with chief complaint of left chest pain and referred to his left back. The complaint is accompanied by cough without sputum and hoarseness. In thoracic CT scan with contrast, we found giant cystic mass suspect malignancy around $17 x 12 \times 18 \mathrm{~cm}$ in left hemithorax, a minimal pericardial effusion, and left pleural effusion. There were positive tumor cell cytoplasm results in vimentin, negative tumor cell cytoplasm in CK, positive tumor cell membrane in CD99, cytoplasm of focal positive tumor cells in EMA, and negative tumor cells in CD34 which supported a solitary fibrous tumor in the immunohistochemical staining analysis. Doxorubicin-Ifosfamide regimen was the choice of chemotherapy palliative treatment in the case report. In the CT scan evaluation of thorax with contrast, we found stable disease (RECIST criteria) with improve quality of life (QOL) according to EQ-5D-3L, 11111 indicated no problems in 5 dimensions, such as mobility, self-care, usual activities, pain or discomfort, and anxiety or depression. Conclusion: Mediastinal SFT is a rare spindle cell neoplasm, and the diagnosis requires pathological and immunohistochemical staining analysis. DoxorubicinIfosfamide regimen can be proposed as a palliative chemotherapy regimen, which has been shown to improve QOL patients in Mediastinal SFT. EQ-5D is a simple tool that can be used to measure QOL such as mobility, self-care, usual activities, pain or discomfort, and anxiety or depression.
\end{abstract}

Keywords: Solitary fibrous tumor, mediastinum tumor, quality of life, chemotherapy palliative, immunohistochemical staining analysis

Correspondence: Aryo Dirgantara Putra, RSUD Abdul Wahab Sjahranie, Samarinda, Kalimantan Timur, Indonesia/ Departemen Pulmonologi dan Ilmu Kedokteran Respirasi, Fakultas Kedokteran Universitas Airlangga/RSUD Dr. Soetomo. Jl. Mayjen. Prof. Dr. Moestopo 6-8 Surabaya 60286. E-mail: dirgantara.aryo@gmail.com

\section{PENDAHULUAN}

Solitary Fibrous Tumor (SFT) merupakan tumor mesenkimal yang paling sering terjadi di pleura, meskipun juga telah ditemukan di berbagai ekstra serosa lainnya. SFT biasanya terjadi pada orang dewasa paruh baya yang berusia 20-70 tahun (median 50 tahun) tanpa perbedaan antara jenis kelamin. ${ }^{1}$ SFT pertama kali digambarkan sebagai tumor primer sel spindel pleura oleh Klemperer dan Rabin pada tahun 1931. Kebanyakan SFT tumbuh lambat tanpa rasa sakit dan biasanya dilakukan pengobatan dengan reseksi bedah. Rata-rata tingkat kelangsungan hidup SFT 10 tahun, dengan rata-rata yang dilaporkan untuk pasien yang telah menjalani reseksi bedah komplit berkisar antara $54 \%$ hingga $89 \%$. Sekitar 20\%-30\% pasien dengan SFT yang mengalami rekurensi lokal dan atau metastasis jauh, memiliki keterbatasan pilihan pengobatan yang efektif. SFT umumnya dianggap sebagai tumor yang kemoresisten relatif, tetapi untuk saat ini kegunaan kemoterapi sistemik untuk SFT belum ditetapkan dalam kepustakaan. $^{3}$

SFT mediastinum merupakan neoplasma sel spindel yang jarang dan awalnya didokumentasikan 
oleh Witkin dan Rosai pada tahun 1989. Sekitar 1 hingga $8 \%$ tumor intratoraks ini telah dilaporkan terjadi di mediastinum. Keluhan utama SFT mediastinum dapat berupa batuk, sesak napas atau nyeri dada, atau dapat terjadi sebagai asymptomatic incidental mass. ${ }^{4-6}$ SFT mediastinum dapat memiliki perjalanan klinis yang lebih agresif, menurut Witkin dan Rosai, 64\% dari SFT mediastinum menunjukkan perilaku klinis agresif, termasuk 3 dari 11 (27\%) pasien yang meninggal karena progresivitas penyakit. Meskipun SFT merupakan tumor jinak, sekitar $20 \%$ SFT memiliki potensi ganas. ${ }^{7,8}$ Tindakan bedah eksisi merupakan pilihan pengobatan untuk SFT, dengan tingkat kelangsungan hidup 5 tahun hampir $100 \%$. Tumor kecil $(<5 \mathrm{~cm})$ direseksi melalui bedah torakoskopi dengan bantuan video (VATS), sedangkan tumor besar memerlukan torakotomi dengan reseksi luas, lobektomi, atau pneumonektomi. ${ }^{9}$ Namun, ketika tumor tidak dapat diangkat melalui pembedahan atau ketika terjadi metastasis, kemoterapi dan atau radioterapi dapat diusulkan sebagai terapi paliatif. ${ }^{10}$ Berikut kami laporkan kasus seorang pasien laki-laki berusia 19 tahun dengan Mediastinal SFT dengan perspektif kemoterapi paliatif.

\section{KASUS}

Seorang mahasiswa laki-laki berusia 19 tahun datang dengan keluhan nyeri dada kiri sejak 5 bulan sebelum masuk rumah sakit (MRS). Keluhan terasa semakin memberat ketika pasien batuk dan nyeri dada kiri ini terasa menjalar hingga ke punggung kiri. Keluhan disertai dengan batuk tidak berdahak, suara serak, dan tidak ada penurunan berat badan maupun nafsu makan. Keluhan suara serak dan napas menjadi pendek-pendek dirasakan pasien kurang lebih 3 bulan sebelum MRS. Pasien sempat rawat inap di RS Mesir selama 7 hari (pasien merupakan mahasiswa yang sedang bersekolah di Mesir) dan telah dilakukan CT scan toraks dengan kontras, namun pasien minta pulang dan ingin melanjutkan pengobatan di Indonesia.

Pada bulan Juli 2017, pasien menjalani rawat inap untuk proses penegakan diagnosis. Pemeriksaan $\beta$ HCG, total kuantitatif < $2.00 \mathrm{mUI} / \mathrm{ml}$ dan LDH 1004 U/L. Pada pemeriksaan foto toraks, posisi PA tampak trakea deviasi ke kanan, mediastinum dan jantung deviasi ke kanan, didapatkan opasitas homogen pada hemitoraks kiri. CT scan toraks dengan kontras (Gambar 1) didapatkan kesan suatu cystic mass mengarah pada malignant mediastinal mass, efusi perikardium minimal, dan efusi pleura kiri. Gambaran lesi kistik (19HU) dengan komponen solid di dalamnya (56HU) batas sebagian tidak tegas, tepi irreguler dengan ukuran $17 \times 12 \times 18 \mathrm{~cm}$ pada hemitoraks kiri, yang pada pemberian kontras tampak kontras enhancement (75HU). Massa tampak menyebabkan compressive atelektasis lingual paru kiri, segmen superior dan anterobasal lobus inferior paru kiri, dan segmental compressive atelektasis segmen posterolateral basal lobus inferior paru kiri. Massa juga mendesak pusat bronkus kiri ke inferior serta menempel dan mendesak mediastinum, organ-organ mediastinum dan great vessels ke sisi kanan dengan batas yang masih tegas. Selain itu, massa juga mendesak esophagus ke sisi kanan sehingga mendesak arteri subclavia kiri ke sisi superior. Tampak subpleural nodul (36HU) di anteroinferolateral hemitoraks kiri yang mendesak hemidiafragma kiri ke inferior. Tampak densitas cairan (22HU) di cavum pleura kiri dan minimal densitas cairan (13HU) di cavum pericardium. Pada FNAB CT guiding didapatkan kesan poorly differentiated carcinoma (undiffentiated carcinoma). Pemeriksaan fiber optic bronchoscopy (FOB) (Gambar 2) tampak pendesakan massa ekstralumen menyebabkan obstruksi total orificium upper portion paru sinistra dan pendesakan massa ekstralumen menyebabkan obstruksi total lower portion paru sinistra. Pemeriksaan sitologi bronchoalveolar lavage (BAL) tidak ditemukan sel ganas, pemeriksaan core biopsy didapatkan malignant tumor dengan diagnosis banding 1) Sarcoma; 2) Carcinoma poorly differentiated. Analisa imunohistokimia (Gambar 3) didapatkan hasil vimentin positif pada sitoplasma sel tumor, CK negatif pada sitoplasma sel tumor, CD99 positif pada membran sel tumor, EMA positif fokal pada sitoplasma sel tumor, dan CD34 negatif pada sel tumor, dengan kesimpulan mendukung suatu SFT.

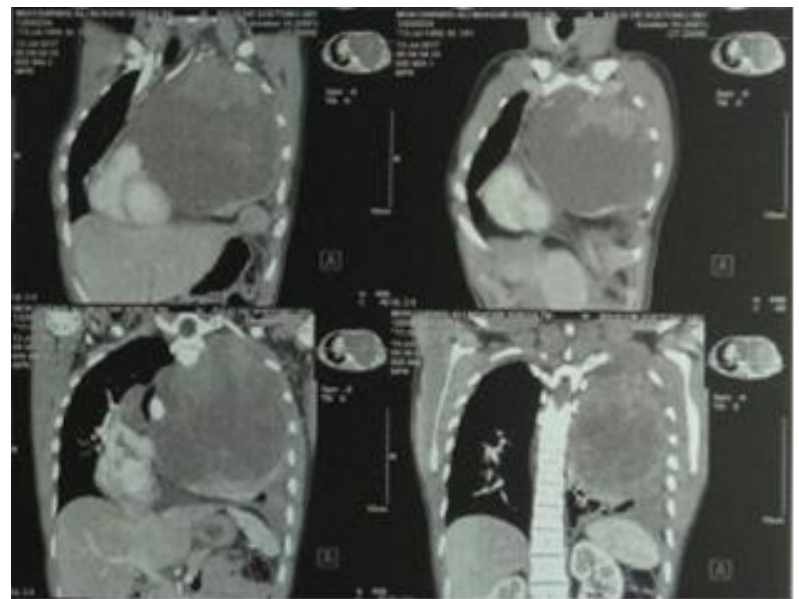

Gambar 1. CT scan toraks dengan kontras tanggal 13 Juli 2017

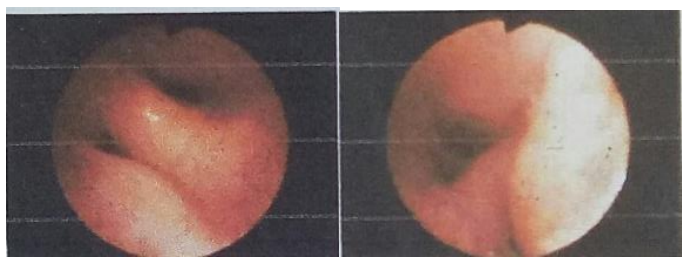

Gambar 2. Pemeriksaan FOB tangan tanggal 17 Juli 2017 
Pada awal September 2017 kasus didiskusikan bersama multidisciplinary team (MDT) dengan permasalahan terapi. Hasil diskusi adalah pemberian kemoterapi neoadjuvant regimen DoxorubicinIfosfamide (AI), evaluasi CT scan toraks dengan kontras tiap 2 siklus, dan rencana bedah eksisi jika ukuran tumor telah mengecil. Sebelum kemoterapi neoadjuvant, pasien melakukan pemeriksaan faal paru (Tabel 1) dengan hasil restriksi berat. Dari pemeriksaan ekokardiografi (Gambar 4), didapatkan hasil fungsi LV \& RV masih normal, LV wallmotion normokinetik cendrung hiperkinetik dengan gambaran terdapat massa tumor di hemitoraks kiri yang mendesak jantung ke kanan, sehingga sulit untuk mendapatkan echowindow yang wajar. Kami hanya mendapatkan ventrikel kiri, atrium kiri, aorta $(3 \mathrm{CH})$ sebagian dengan gambaran pericardial efusi moderate-severe (terutama di bagian tengah apikal), tetapi belum ada tanda tanda tamponade jantung. Penilaian kualitas hidup pasien dengan menggunakan kuesioner EQ-5D-3L sebelum menerima kemoterapi neoadjuvant didaptkan hasil EQ-5D-3L 11222 yang mengindikasikan tidak adanya masalah pada mobilitas dan perawatan diri, namun didapatkan beberapa masalah pada kegiatan sehari-hari, nyeri atau ketidaknyamanan, dan kecemasan atau depresi.

Tabel 1. Pemeriksaan Faal Paru

\begin{tabular}{lccc}
\hline Test & Subyek & Prediktet & \%Normal \\
\hline VC & 1,23 & 3,90 & 31,5 \\
FVC & 1,31 & 3,90 & 33,6 \\
FEV 1 & 1,16 & 3,34 & 34,7 \\
MBC & 43,20 & 166,87 & 25,9 \\
\hline
\end{tabular}

Kemudian setelah dilakukan kemoterapi neoadjuvant sebanyak 2 siklus, kami lakukan pemeriksaan CT scan toraks evaluasi dengan kontras (Gambar 5) pada tanggal 6 Desember 2017 dan didapatkan kesan progressive disease (kriteria RECIST).

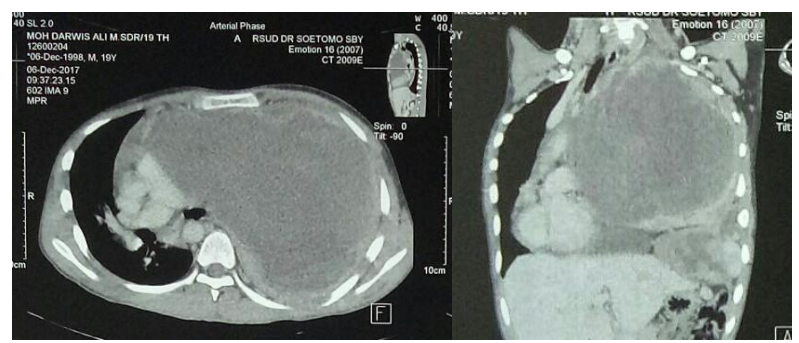

Gambar 5. Tampak lesi kistik (19HU) dengan komponen solid di tepinya $(46 \mathrm{HU})$ batas tidak tegas, tepi irregular dengan ukuran 19,4x15,3x18,30 cm pada mediastinum anterior-medius-posterior yang pada pemberian kontras tampak kontras enhancement (68HU). Masih tampak subpleural nodul di lobus inferior paru kiri dengan ukuran relatif membesar. Lesi solid di lobus inferior paru kiri dapat merupakan gambaran metastase (lesi baru). Multiple lymphnode di upper \& lower paratracheal, subcarina dan axilla kanan kiri dengan ukuran relatif membesar. Efusi pleura kiri \& efusi pericard.

Pada 13 Desember 2017 pasien kembali didiskusikan bersama MDT dengan permasalahan terapi (pasien dan keluarga pasien menolak tindakan operasi), dan hasil diskusi saat itu adalah melanjutkan kemoterapi regimen Doxorubicin-Ifosfamide sebagai terapi paliatif hingga siklus ke-4 dan dievaluasi CT scan toraks dengan kontras tiap 2 siklus. Kemudian setelah
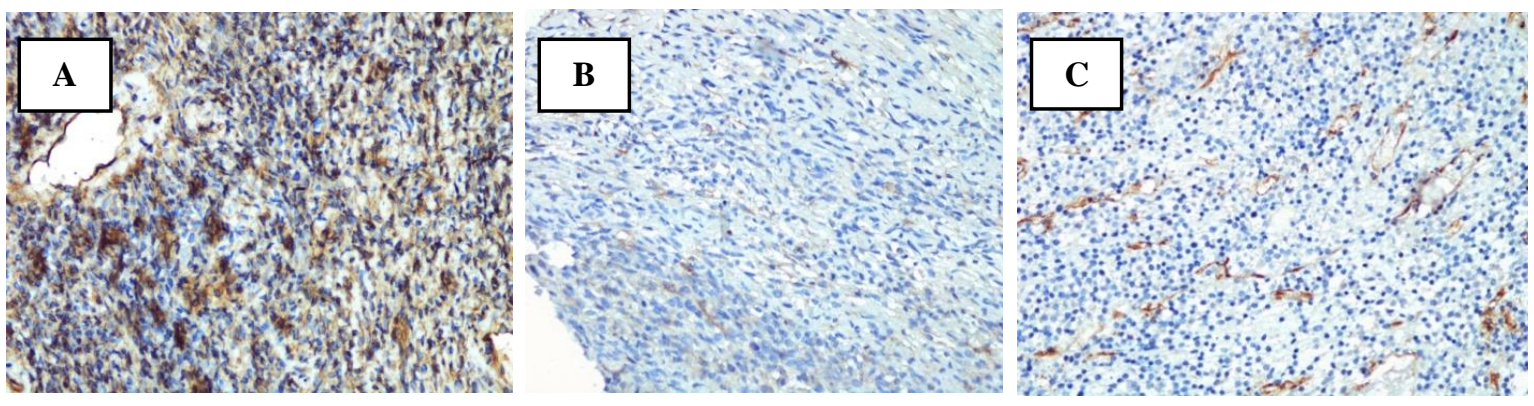

Gambar 3. Pemeriksaan imunohistokimia tanggal 25 Juli 2017

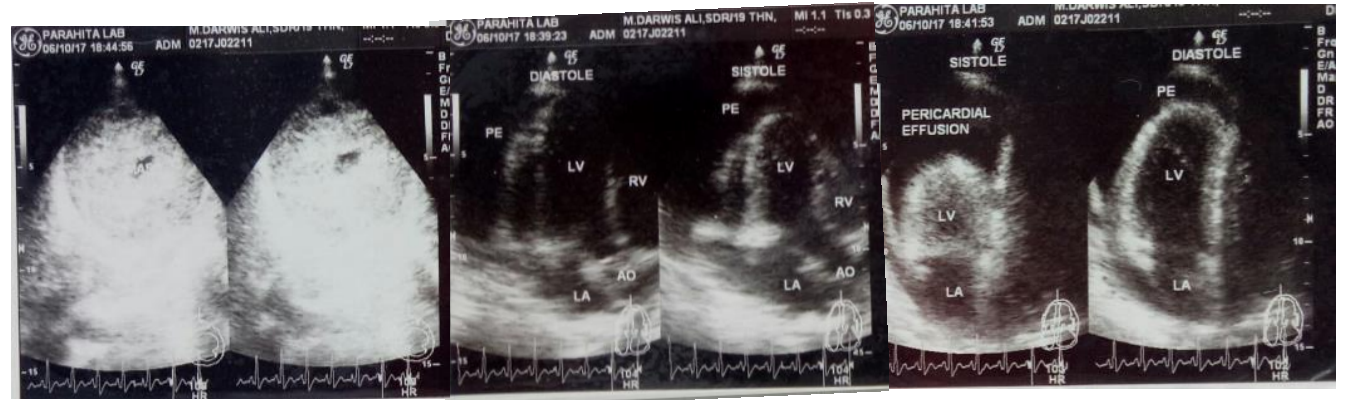

Gambar 4. Ekokardiografi tanggal 6 Oktober 2017 


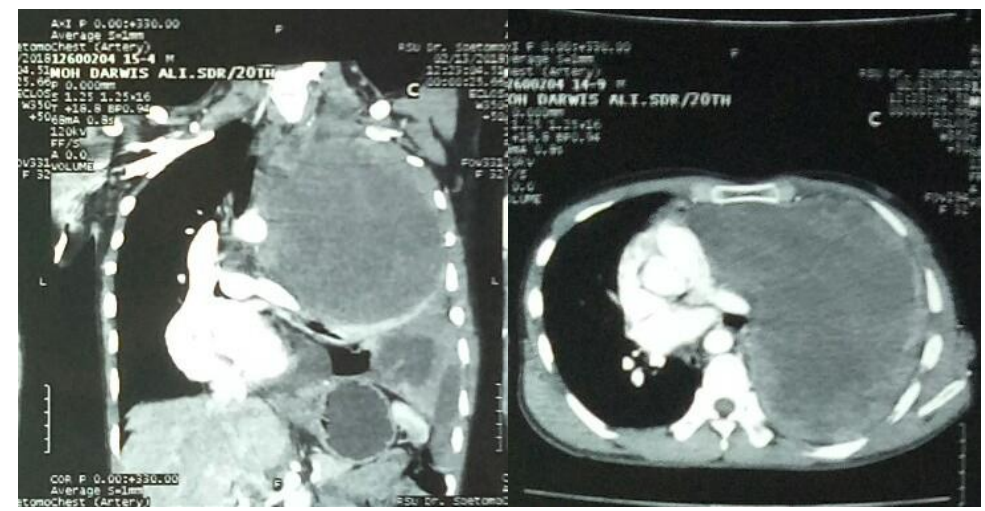

Gambar 6. Tampak lesi kistik (21HU) dengan komponen solid di tepinya (52HU) batas tidak tegas, tepi irregular dengan ukuran $11,5 \times 14,6 \times 21,6 \mathrm{~cm}$ pada mediastinum anterior-medius-posterior yang pada pemberian kontras tampak kontras enhancement (68HU). Masih tampak gambaran subpleura nodul di lobus inferior paru kiri dengan ukuran relatif tetap. Lesi solid di lobus inferior paru kiri dapat merupakan gambaran metastase. Multiple lymphnode di upper paratracheal, axilla kanan kiri, paraaorta, lower paratracheal kanan. Efusi Pericard.

dilakukan kemoterapi paliatif sebanyak 2 siklus, kami lakukan pemeriksaan CT scan toraks evaluasi dengan kontras (Gambar 6) pada tanggal 13 Februari 2018 dan didapatkan hasil stable disease (kriteria RECIST).

Pada kondisi akhir setelah pemberian kemoterapi paliatif didapatkan hasil EQ-5D-3L 11111. Tidak ditemukan indikasi adanya masalah pada mobilitas, perawatan diri, kegiatan sehari-hari, nyeri atau ketidaknyamanan, dan kecemasan atau depresi pada pasien.

\section{PEMBAHASAN}

SFT merupakan kelompok heterogen langka dari neoplasma jinak dan ganas yang berasal dari mesenkimal. Kebanyakan SFT jinak terjadi baik di lokasi intratoraks dan ekstratoraks. SFT mediastinum jarang terjadi, neoplasma tumbuh lambat, dan paling sering didiagnosis antara usia 50 dan 70. Pada kasus ini, pasien berusia relatif muda pada saat didiagnosis SFT mediastinum. ${ }^{6,11}$ Pasien dapat mengeluhkan batuk, nyeri dada ataupun sesak napas, namun pada banyak kasus bersifat asimptomatik., ${ }^{3,12}$ Pada kasus ini, pasien datang dengan keluhan utama nyeri dada kiri, nyeri dada kiri hingga menjalar ke punggung kiri, dan terasa memberat terutama ketika pasien batuk. Keluhan juga disertai dengan batuk tidak berdahak serta suara menjadi serak.

Secara radiologis, pada foto toraks gambaran SFT dapat berupa massa lobular, tepi regular, batas tidak tegas yang melibatkan permukaan pleura atau fisura, dan sering berada di dalam bagian inferior toraks. CT scan toraks umumnya dianggap sebagai prosedur optimal untuk menentukan ukuran dan lokasi tumor, dan sangat penting untuk rencana tindakan pembedahan. Secara umum, SFT intratoraks dengan ukuran kecil dapat berupa massa berbatas tegas dan homogen, yang membentuk sudut tumpul dengan pleura. Hiperdensitas relatif dari massa kemungkinan besar karena kandungan kolagennya yang tinggi. Pada SFT intratoraks dengan ukuran besar, dapat tampak gambaran heterogen dengan beragam pola karena degenerasi kistik, klasifikasi, perdarahan, dan nekrosis. Heterogenitas tumor lebih sering terjadi pada jenis yang ganas dan juga didapatkan hipervaskularisasi dan pembuluh-pembuluh kolateral. Pada MRI didapatkan gambaran sinyal intensitas rendah hingga menengah dan homogen (T1), sinyal intensitas yang bervariasi dan tidak homogen (T2). Area hiperintensitas T2 sesuai dengan perdarahan, myxoid, dan degenerasi kistik, terutama pada tumor besar. Area hiperensensitas $\mathrm{T} 2$ berhubungan dengan stroma kolagen dan fibrosis, serta adanya peningkatan heterogen yang ditandai setelah pemberian gadolinium IV pada pos kontras T1. Pada pemeriksaan ultrasonografi didapatkan gambaran biasanya hipoekoik, lebih besar mungkin memiliki gambaran heterogen karena nekrosis dan degenerasi kistik, dan pada pemeriksaan FDG-PET didapatkan hasil non-FDG-avid pada SFT jinak, dan FDG-avid pada SFT ganas. ${ }^{3,9,13}$ Pada kasus ini hanya dilakukan pemeriksaan radiologi berupa rontgen toraks posisi PA dan CT scan toraks dengan kontras dan tidak dilakukan pemeriksaan MRI toraks dan FDG PET, karena dengan pemeriksaan CT scan toraks dengan kontras kami dapatkan kesan suatu cystic mass yang mengarah pada malignant mediastinal mass, efusi perikardium minimal, dan efusi pleura kiri.

Secara histologis, SFT tersusun atas sel-sel spindel dengan latar belakang stroma kolagen, seringkali dalam pola melingkar atau tanpa pola. Tumor tampak hipervaskuar dan memiliki kecenderungan untuk mengalami degenerasi myxoid. Analisis imunohistokimia memiliki peran dalam penegakan diagnosis dan tatalaksana SFT. Sekitar 70 - 80\% SFT jinak, positif pada pewarnaan imunohistokimia CD34. CD34 merupakan marker normal pada endothelium dan vaskular tumor. Demikian pula dengan B-cell 
lymphoma (bcl-2), yang merupakan marker diferensiasi terminal, dan vimentin juga positif pada SFT jinak. Sitokeratin, S-100 dan protein p53 menunjukan peningkatan ekspresi pada SFT ganas. Pemeriksaan tambahan pada pewarnaan imunohistokimia CD99 didapatkan hampir $75 \%$ dari tumor reaktif untuk CD99.9,12,14,15 Pada kasus ini, telah dilakukan pemeriksaan pewarnaan imunohistokimia dan didapatkan hasil imunohistokimia sitoplasma sel tumor positif pada vimentin, sitoplasma sel tumor negatif pada CK, membran sel tumor positif pada CD99, sitoplasma sel tumor positif fokal pada EMA, dan sel tumor negatif pada CD34. Pada beberapa kasus SFT ganas, terkadang didapatkan hasil negatif pada pewarnaan imunohistokimia CD34. Kehilangan ekspresi CD34 dan sitokeratin positif pada SFT biasanya berkorelasi dengan tumor tingkat tinggi dan hasil yang tidak menguntungkan. ${ }^{16}$

Kombinasi berbagai pemeriksaan penunjang seperti pencitraan, patologi anatomi, dan imunohistokimia digunakan untuk memprediksi potensi ganas suatu SFT. Dikatakan potensi ganas jika pada pencitraan ditemukan ukuran massa lebih dari $10 \mathrm{~cm}$, peningkatan interval ukuran, infiltrasi ke jaringan lunak yang berdekatan dan invasi dinding dada, nekrosis dan perdarahan yang luas, dan adanya efusi pleura. Pada pemeriksaan patologi ditemukan lebih dari 4 mitosis per lapang pandang, peningkatan seluleritas, peningkatan pleomorfisme, nekrosis dan perdarahan yang luas. Pada pemeriksaan imunohistokima didapatkan kehilangan ekspresi CD34, didapatkan ekspresi sitokeratin, ekspresi p53, dan ekspresi S-100. Pada kasus ini, SFT berpotensi ganas karena pada CT scan toraks dengan kontras tampak lesi kistik (19HU) dengan komponen solid di dalamnya (56HU) batas sebagian tidak tegas, tepi irreguler dengan ukuran $17 \times 12 \times 18 \mathrm{~cm}$ pada hemitoraks kiri, yang pada pemberian kontras tampak kontras enhancement (75HU) dan tampak densitas cairan (22HU) di cavum pleura kiri dan minimal densitas cairan (13HU) di cavum pericardium. Pada imunohistokimia didapatkan sel tumor negatif pada CD34 (kehilangan ekspresi CD34).

Pilihan terapi pada SFT adalah reseksi bedah ekstensif. Bedah eksisi bersifat kuratif pada SFT jinak. Tumor kecil $(<5 \mathrm{~cm})$ direseksi melalui bedah torakoskopik dengan bantuan video (VATS), sedangkan tumor besar memerlukan torakotomi dengan reseksi luas, lobektomi, atau pneumonektomi. Pada kasus SFT ganas, SFT akan sering kambuh dan berkembang meskipun radiasi adjuvant atau kemoterapi telah diberikan. Dalam kasus kekambuhan, reseksi bedah menawarkan kesempatan terbaik untuk penyembuhan lengkap. Namun, ketika tumor tidak dapat diangkat melalui pembedahan atau ketika terjadi metastasis, kemoterapi dan atau radioterapi dapat diusulkan sebagai terapi paliatif. Radioterapi dapat sebagai pilihan terapi paliatif penyakit lokal simptomatik, misalnya nyeri atau kompresi saluran napas. $5,9,10$

Pada kasus ini, awalnya hasil diskusi bersama MDT telah sepakat akan memberikan kemoterapi neoadjuvant regimen Doxorubicin-Ifosfamide, dengan evaluasi CT scan toraks dengan kontras tiap 2 siklus dan rencana bedah eksisi jika ukuran tumor telah mengecil. Kemudian pasien menjalani pemberian kemoterapi neoadjuvant regimen Doxorubicin-Ifosfamide, namun setelah 2 siklus dan dilakukan evaluasi CT scan toraks dengan kontras, pasien dan keluarga pasien menolak tindakan operasi, sehingga dilakukan kembali diskusi bersama MDT dan menyepakati kemoterapi regimen Doxorubicin-Ifosfamide dilanjutkan hingga siklus ke-4 sebagai terapi paliatif.

Pasien dengan penyakit pernapasan memiliki banyak kebutuhan fisik, psikologis, sosial dan eksistensial atau spiritual sepanjang perjalanan penyakit mereka. Baik pencegahan dan pengobatan penyakit paru perlu ditingkatkan jika dampaknya terhadap umur menjadi lebih panjang dan kualitas hidup individu serta beban ekonomi mereka pada masyarakat harus dikurangi. Terapi paliatif ataupun perawatan paliatif bertujuan untuk mencegah dan mengurangi penderitaan dengan mengendalikan gejala dan memberikan dukungan kepada pasien dan keluarga untuk mempertahankan dan meningkatkan kualitas hidup mereka. ${ }^{17}$

EQ-5D merupakan ukuran standar status kesehatan yang dikembangkan oleh EuroQol Group untuk memberikan ukuran kesehatan yang sederhana dan umum untuk penilaian klinis dan ekonomi. Sistem deskriptif EQ5D-3L terdiri dari 5 dimensi, yaitu mobilitas, perawatan diri, kegiatan sehari-hari, nyeri atau ketidaknyamanan, dan kecemasan atau depresi. Setiap dimensi memiliki 3 tingkatan, yaitu tidak ada masalah, masalah menengah, dan masalah ekstrim. ${ }^{18}$ Dalam kasus ini, pada kondisi awal sebelum kemoterapi neoadjuvant didapatkan hasil EQ-5D3L 11222 yang mengindikasikan tidak adanya masalah pada mobilitas dan perawatan diri, namun didapatkan masalah menengah pada kegiatan sehari-hari, nyeri atau ketidaknyamanan, dan kecemasan atau depresi. Pada kondisi setelah pemberian kemoterapi paliatif, didapatkan hasil EQ-5D-3L 11111, yang mengindikasikan tidak adanya masalah pada 5 dimensi tersebut, yang ditandai dengan perbaikan klinis terhadap keluhan batuk, nyeri dada kiri hingga menjalar ke punggung, dan suara serak. Bahkan pasien yang pada awalnya tidak mampu membaca surat Al-Fatihah, setelah kemoterapi 2 siklus pasien mampu membaca Al-Qur'an hingga 1 Juz. 
Park, dkk telah melakukan penilitian retrospektif pada 15 pasien SFT yang mendapat kemoterapi berbasis Doxorubicin sebagai lini pertama dengan dosis 60 $\mathrm{mg} / \mathrm{m}^{2}$ dan dosis $75 \mathrm{mg} / \mathrm{m}^{2}$, pemberian Doxorubicin disertai pemberian Ifosfamide dengan dosis $10 \mathrm{~g} / \mathrm{m}^{2} .^{3}$ Pada kasus ini, pasien mendapatkan kemoterapi regimen Doxorubicin-Ifosfamide dengan dosis Doxorubicin 25 $\mathrm{mg} / \mathrm{m}^{2}$ dan dosis Ifosfamid $3000 \mathrm{mg} / \mathrm{m}^{2}$. Pada 12 pasien SFT yang mendapatkan kemoterapi regimen Doxorubicin-Ifosfamide, terdapat 11 pasien dengan kondisi respon kemoterapi stable disease (kriteria RECIST) dan 1 pasien dengan kondisi respon kemoterapi progressive disease (kriteria RECIST). ${ }^{3}$ Pada kasus ini, dilakukan pemeriksaan CT scan toraks dengan kontras evaluasi setelah kemoterapi neoadjuvant 2 siklus, dan didapatkan kesan progressive disease (kriteria RECIST). Pada CT scan toraks dengan kontras evaluasi setelah kemoterapi paliatif 2 siklus, didapatkan kesan stable disease (kriteria RECIST). Setelah mendapatkan kemoterapi paliatif 4 siklus, dilakukan pemeriksaan faal paru evaluasi dan didapatkan hasil restriksi ringan dengan nilai FVC 72 (sebelum kemoterapi nilai FVC 33,6, suatu restriksi berat). Hal ini menunjukan adanya perbaikan secara objektif selaras dengan evaluasi EQ-5D-3L setelah pasien mendapat kemoterapi paliatif dan akan dilakukan pemeriksaan ekokardiografi evaluasi untuk menilai fungsi jantung dan efek samping Doxorubicin terhadap fungsi jantung, evaluasi CT scan toraks dengan kontras untuk menilai respon kemoterapi paliatif pada kasus ini. Pada penelitian Park, dkk didapatkan gambaran median progression free survival (PFS) 4,6 bulan (interval kepercayaan $95 \%=4,0-5,3$ bulan), median overall survival (OS) semua pasien dari awal tegaknya diagnosis adalah 10,3 tahun (interval kepercayaan 95\% = 5,7-14,9 tahun), dan median OS semua pasien dari awal kemoterapi adalah 22,8 bulan (interval kepercayaan $95 \%=3,1-42,6$ bulan). ${ }^{3}$

\section{RINGKASAN}

SFT mediastinum merupakan neoplasma sel spindel yang jarang. Sekitar 1 hingga $8 \%$ tumor intratoraks ini telah dilaporkan terjadi di mediastinum. Keluhan utama SFT mediastinum dapat berupa batuk, sesak napas atau nyeri dada, atau dapat terjadi sebagai asymptomatic incidental mass. Penegakan diagnosis memerlukan pemeriksaan patologi dan pewarnaan imunohistokimia. Kemoterapi dan radioterapi dapat diusulkan sebagai terapi paliatif ketika tumor tidak dapat diangkat melalui pembedahan atau ketika terjadi metastasis.
Pada laporan kasus ini, dilaporkan seorang pria 19 tahun dengan keluhan nyeri dada kiri sejak 5 bulan sebelum masuk RS, keluhan terasa semakin memberat ketika pasien batuk, nyeri dada kiri ini pun menjalar hingga ke punggung kiri, keluhan disertai dengan batuk tidak berdahak dan suara serak. Pada gambaran CT scan toraks dengan kontras didapatkan malignant mass paru kiri ukuran 17 x12 x $18 \mathrm{~cm}$ dengan Multiple lymphnodes di peribronkhial kanan kiri, subcarina, lower paratracheal kanan, axilla kiri dan subpleural nodul anteroinferolateral kiri dengan minimal efusi pericard, dan efusi pleura kiri. Pemeriksaan pewarnaan imunohistokimia mendukung suatu SFT. Terapi paliatif berupa kemoterapi regimen Doxorubicin-Ifosfamide merupakan pilihan terapi pada kasus ini, dikarenakan pasien dan keluarga pasien menolak tindakan operasi. Pada CT scan evaluasi toraks dengan kontras, didapatkan gambaran stable disease (kriteria RECIST) dengan ukuran kualitas hidup yang membaik dengan EQ-5D-3L, 11111 yang mengindikasikan tidak adanya masalah pada 5 dimensi, yaitu mobilitas, perawatan diri, kegiatan sehari-hari, nyeri atau ketidaknyamanan, dan kecemasan atau depresi.

\section{DAFTAR PUSTAKA}

1. Vanfleteren LEGW, Peulen HMU, Creytens DHK V, et al. Complete Metabolic Remission of an Irresectable Mediastinal Solitary Fibrous Tumour with Concurrent Chemoradiation. Thorax 2009; 64: 822-823.

2. Künzel J, Hainz M, Ziebart $\mathrm{T}$, et al. Head and Neck Solitary Fibrous Tumors: A Rare and Challenging Entity. Eur Arch Oto-Rhino-Laryngology Off J Eur Fed OtoRhino-Laryngological Soc Affil with Ger Soc Oto-RhinoLaryngology - Head Neck Surg 2016; 273: 1589-1598.

3. Park MS, Ravi V, Conley A, et al. The Role of Chemotherapy in Advanced Solitary Fibrous Tumors: A Retrospective Analysis. Clin Sarcoma Res 2013; 3: 7.

4. Soomro NH, Pervaiz S, Hussain A, et al. Solitary Fibrous Tumor of the Mediastinum: A Rare Tumor at a Rare Site.

5. De Raet J, Sacré R, Hoorens A, et al. Malignant Giant Solitary Fibrous Tumor of the Mediastinum. J Thorac Oncol 2008; 3: 1068-1070.

6. Webb AJ, Yassin AS, Saeed A, et al. Mediastinal Solitary Fibrous Tumor Diagnosed by Endobronchial UltrasoundDirected Biopsy. Am J Case Rep 2017; 18: 549-552.

7. Song S, Li P. Giant Solitary Fibrous Tumor of Posterior Mediastinum: A Case Report. J Nucl Med Radiat Ther; 07. Epub ahead of print 1 January 2016. DOI: 10.4172/21559619.1000276.

8. Gannon BR, O'Hara CD, Reid K, et al. Solitary Fibrous Tumor of the Anterior Mediastinum: A Rare Extrapleural Neoplasm. Tumori 2007; 93: 508-510.

9. Chick JFB, Chauhan NR, Madan R. Solitary Fibrous Tumors of the Thorax: Nomenclature, Epidemiology, 
Radiologic and Pathologic Findings, Differential Diagnoses, and Management. AJR Am J Roentgenol 2013; 200: W238-48.

10. Levard A, Derbel O, Méeus P, et al. Outcome of Patients with Advanced Solitary Fibrous Tumors: The Centre Léon Bérard Experience. BMC Cancer 2013; 13: 109.

11. Lu C, Ge D. A Large Solitary Fibrous Tumor of the Mediastinum. Chinese J Clin Oncol 2006; 3: 452-454.

12. Ginat DT, Bokhari A, Bhatt S, et al. Imaging Features of Solitary Fibrous Tumors. AJR Am J Roentgenol 2011; 196: 487-495.

13. Saynak M, Veeramachaneni NK, Hubbs JL, et al. Solitary Fibrous Tumors of Chest: Another Look with the Oncologic Perspective. Balkan Med J 2017; 34: 188-199.

14. Magdeleinat P, Alifano M, Petino A, et al. Solitary Fibrous Tumors of the Pleura: Clinical Characteristics, Surgical Treatment and Outcome. Eur J Cardio-Thoracic Surg Off J Eur Assoc Cardio-Thoracic Surg 2002; 21: 1087-1093.
15. Alawi F, Stratton D, Freedman PD. Solitary Fibrous Tumor of the Oral Soft Tissues: A Clinicopathologic and Immunohistochemical Study of 16 Cases. Am J Surg Pathol 2001; 25: 900-910.

16. Yokoi T, Tsuzuki T, Yatabe Y, et al. Solitary Fibrous Tumour: Significance of P53 and CD34 Immunoreactivity in Its Malignant Transformation. Histopathology 1998; 32: 423-432.

17. Bajwah S, Namisango E, Janssen DJA, et al. The Need for Palliative Care. ERS Monogr 2016; 2016: 21-34.

18. Reenen M van, Oppe M, Boye KS, et al. EQ-5D-3L User Guide: Basic Information on How to Use the EQ-5D-3L Instrument. Rotterdam, https://euroqol.org/wpcontent/uploads/2019/10/EQ-5D-3L-User-Guide_version6.0.pdf (2018). 